\title{
Effect of the Implementation of Occupational Safety and Health (K3) Policy and the Establishment of the Occupational Safety and Health Committee (P2K3) on the Level of Occupational Safetyand Health of Employees of PT Yuasa Battery Indonesia, Tangerang
}

\author{
Harjoyo $^{1}$, Desilia Purnama Dewi ${ }^{2}$, Sugiyarto ${ }^{3}$ \\ Universitas Pamulang
}

\author{
Dosen00808@unpam.ac.id¹,Sugiyarto_01722@unpam.ac.id², dosen00810@unpam.ac.id³
}

\begin{abstract}
This analysis research is about "The Effect of Implementation Health and Safety Policy, Establishment of The Health and Safety Committees toward Health and Safety Level of PT Yuasa Battery Indonesia, Tangerang Employees". The study attempted to examine a phenomena and to gain empirical evident, as well as to get a brief data on the influence of implementation occupational health and safety policy, establishment of the health and safety committees toward health and safety level of PT Yuasa Battery Indonesia, Tangerang employees. The study applied descriptive and inductive of multivariat regresion method it's include 94 respondents as the samples. The samples were selected through proporsionate stratified sampling. The statistical tool were used is SPSS 17 software as the means to examine the data. The findings could be concluded as follows: (1) There was positive effect from all independent variables toward health and safety level of PT Yuasa Battery Indonesia, Tangerang employees within value influence $36,9 \%$. (2) The results of this research indicated that Establishment of The Health and Safety Committees was the greatest affecting to health and safety level of PT Yuasa Battery Indonesia, Tangerang employees was as much as $26,0 \%$. (3) Meanwhile there are positive influence of implementation health and safety policy was equal to $23,7 \%$. From these results, it is suggested that the company should pay attention to these two variables, namely implementation of the health and safety policy and establishment of the health and safety committees so that the objectives to be achieved is doing efforts to protect workers from the risk of workplace accidents and occupational diseases will be achieved. The smaller or low accidents happened is an indicator of the company's success in implementing health and safety management.
\end{abstract}

Keywords: The Health and Safety Policy, The Health and Safety Committees, Health and Safety of Employees

\section{Introduction}

Occupational safety and health (OSH) is a discipline that cares and protects the safety, health and welfare of people who work in the workplace. Since 1950 the ILO (International Labor Organization) and WHO (World Health Organization) have established a general definition of occupational health, namely: Occupational health must achieve the highest improvement and care in the physical, social fields as workers in any occupation, prevention for every worker for the reduction of health due to their working conditions, protection for 
workers to reduce factors that can harm their health, placement and care for workers in the environment work in accordance with the physical and psychological abilities of workers and summarize the adaptation of each worker to their respective jobs.

The efforts made by the Indonesian government to protect workers are by making laws and government regulations, including:

a) Law of the Republic of Indonesia No. 21 of 2003 concerning Ratification of the ILO Convention No. 81 Concerning Labor Inspection in Industry and Committee (ILO Convention No. 81 concerning Labor Inspection in Industry and Trade).

b) Law of the Republic of Indonesia No. 13 of 2003 concerning Manpower.

c) Law N0. 1 of 1970 concerning Work Safety.

d) Steam Act of 1930 (Stoom Ordonnarie).

e) Steam Regulation of 1930 (Stoom Verordening).

f) Government Regulation No. 19 of 1973 concerning Management and Supervision of Work Safety in the Mining Sector.

g) Government Regulation No. 11 of 1979 concerning Work Safety on Oil and Gas Purification and Processing.

Related to efforts to protect the workforce, PT Yuasa Battery Indonesia, one of the battery manufacturing industry companies for YUASA brand motorized vehicles, is located on Jalan M.H. Thamrin No. 1 Tangerang-Banten is to create a work safety policy and form a committee to guide occupational safety and health or often referred to as P2K3. PT Yuasa Battery Indonesia views the workforce as a very important company asset and is a key management element. As we know that the management element consists of $6 \mathrm{M}$ (men, money, materials, machines, methods, market). Because humans are the main element of management, it is necessary to pay attention to their safety and health, so that it is expected to manage other elements of management well.

\section{Theoritical Review}

Law No. 1 of 1970 concerning Occupational Safety provides a basic framework for the prevention of accidents and the emergence of occupational diseases in the workplace. The main key of the core Work Safety Law is the involvement of workers and the management and work organizations that are in it to improve occupational safety and health (K3) standards. The involvement of workers in the workplace can be achieved through; the existence of labor representatives for $\mathrm{K} 3$ and the formation of organizations

Occupational Health and Safety. Furthermore in Permenaker No. PER-04 / MEN / 1987 concerning P2K3 as well as the Procedure for Appointing Work Safety Experts, Article 1 (d) explains that what is meant by the Committee for Guidance for Occupational Safety and Health, hereinafter referred to as $\mathrm{P} 2 \mathrm{~K} 3$, is an auxiliary body in the workplace which is a place of cooperation between employers and workers to develop mutual understanding cooperation and effective participation in the application of OSH. Work Safety Law, Article 10 (1) states that "The Minister of Manpower has the authority to form P2K3 in order to develop cooperation, mutual understanding and effective participation of employers or management and workers in the workplace to carry out joint duties and obligations in the field of K3, in order to facilitate production business. "What is meant by developing cooperation, mutual understanding and effective participation is a form of involvement from both parties. While the duties and obligations of both parties is to launch a production business through enhancing 
OSH performance. In this case, $\mathrm{P} 2 \mathrm{~K} 3$ has a central role in ensuring OHS performance in the workplace.

The task of P2K3 (Committee for Guidance for Occupational Safety and Health) is to provide advice and consideration whether requested or not to employers regarding $\mathrm{K} 3$ issues (based on article 4 (four) of the Republic of Indonesia Permenaker Number PER 04 / MEN / 1987). While the functions are as follows:

a. Collecting and processing data on Occupational Safety and Health (K3) in the workplace.

b. Help show and explain to each workforce regarding, various hazards in the workplace that can cause OSH disorders including fire and explosion hazards and how to overcome them, factors that can affect work efficiency and productivity, personal protective equipment (PPE) for the workforce concerned, the right and safe way and attitude in carrying out their work.

c. Helping Entrepreneurs / Administrators in, determine the corrective action with the best alternative, developing a hazard control system for Occupational Safety and Health, evaluate the causes of accidents, occupational diseases (PAK) and take the necessary steps, develop counseling and research in the areas of occupational safety, company hygiene, occupational health and ergonomics,carry out monitoring of work nutrition and organizing food in the company, Checking the completeness of work safety equipment, developing health services for workers, carry out administration of work safety, company hygiene and occupational health. Assist company leaders in formulating management policies and work guidelines in the context of efforts to improve work safety, company hygiene, occupational health, ergonomics and work nutrition. (based on article 4, Permenaker RI Number PER.04 / MEN / 1987).

According to Suma'mur (2001: 104), occupational safety and health is a series of efforts to create a safe and secure work atmosphere for employees who work in the company concerned. Mathis and Jackson (2002: 245), states that Safety is referring to the protection of one's physical well- being against work-related injuries. Health is referring to general physical, mental and emotional stability in general. According to Mangkunegara (2002: 163) Occupational safety and health is a thought and effort to guarantee the wholeness and perfection of both the physical and spiritual workforce in particular, and humans in general, the work and culture to move towards a just and prosperous society.

According to Mangkunegara (2002: 170), that the cause indicator work safety is:

a) Workplace environment, which includes, preparation and storage of dangerous goods which are not taken into account for security,workspace that is too crowded and crowded,disposing of impurities and waste that is not in place.

b) Use of work equipment, which includes, safety of working equipment that is outdated or damaged, the use of machines, electronic devices without good safety, lighting arrangements, occupational Safety and Health Objectives

According to Mangkunegara (2002: 65) that the purpose of salvation and occupational health are as follows:

a) So that every employee gets a guarantee of safety and health work both physically, socially, and psychologically.

b) So that every equipment and work equipment is used as well as possible selectively.

c) So that all production results are maintained.

d) In order to guarantee the maintenance and improvement of employee nutritional health.

e) In order to increase enthusiasm, work harmony, and work participation.

f) In order to avoid health problems caused by the environment or working conditions. 
g) So that every employee feels safe and protected at work

\subsection{Hypothesis}

H1 mean application of K3 Policy affects the level occupational safety and health, the stronger the policies implemented, the lower the number of occupational accidents that occur.

H2 mean P2K3 formation affects the level of occupational safety and health, the more effective the $\mathrm{P} 2 \mathrm{~K} 3$ performance, the lower the number of work accidents that occur.

H3 mean Both variables, namely the application of the K3 Policy and the establishment of P2K3, together have a positive effect on the level of safety and work.

\section{Research Methodology}

\subsection{Validity Test}

Validity test is useful to find out if there are statements on the questionnaire that must be discarded / replaced because they are considered irrelevant. The technique to measure the validity of the questionnaire is by calculate the correlation between the data in each statement with a total score, using the product moment correlation formula.

An Instrument item is considered valid if it meets the following criteria:

a) If the Pearson Correlation value $>0.3$ is declared valid.

b) If the Pearson Correlation value $<0.3$ is declared invalid.

\subsection{Reliability Test}

A research variable is said to be reliable if it meets the following criteria:

a) If Cronbach Alpha $>0.6$ is declared reliable.

b) If Cronbach Alpha $<0.6$ is declared unreliable

\subsection{Multiple Linear Regression Test}

The dependent variable in this study is the Employee Safety and Health Level. Whereas the independent variable is the Application of K3 Policy and the Establishment of P2K3. This study uses multiple linear regression models using the SPSS program which can be formulated as follows:

$\mathrm{Y}=\alpha+\beta 1 \mathrm{X} 1+\beta 2 \mathrm{X} 2+\varepsilon$

$\mathrm{X} 1$ mean application of K3 Policy X2 mean P2K3 Formation

\subsection{Determination Coefficient Test}

$\mathrm{R}^{2}$ value of 1 , means that the fluctuation of the dependent variable as a whole can be 
explained by the independent variable and there are no other factors that cause the fluctuation of the dependent variable. If the value of $\mathrm{R}^{2}$ ranges from 0 to 1 , it means that the stronger the ability of the independent variable can explain the fluctuation of the dependent variable.

\section{Research Result}

Respondents in this study were employees of PT Yuasa Battery Indonesia, Tangerang numbered 94 people,composed 91 men, women 3.

\subsection{Validity Test Result}

The questionnaire was divided into three main factors, namely the application of the K3 (X1) policy with 14 statement items, the establishment of P2K3 (X2) with 12 statement items, and the level of safety and health (Y) with 24 statement items. So, the number of statements in the questionnaire was 50 statements. According to Masrun (1979) in Solimun (2006: 24), if the correlation coefficient is positive and $>0.3$ then the relevant indicator is considered valid.

Table 1. Validity Test Result

\begin{tabular}{cccc}
\hline Statement & T Value & critical limit & Decision \\
\hline X1.1.1. & 0,75 & 0,3 & Valid \\
X1.1.2 & 0,48 & 0,3 & Valid \\
X1.1.3 & 0,48 & 0,3 & Valid \\
X1.1.4 & 0,75 & 0,3 & Valid \\
X1.1.5 & 0,67 & 0,3 & Valid \\
X1.2.1 & 0,81 & 0,3 & Valid \\
X1.2.2 & 0,81 & 0,3 & Valid \\
X1.2.3 & 0,75 & 0,3 & Valid \\
X1.3.1 & 0,73 & 0,3 & Valid \\
X1.3.2 & 0,48 & 0,3 & Valid \\
X1.3.3 & 0,57 & 0,3 & Valid \\
X1.4.1 & 0,57 & 0,3 & Valid \\
X1.4.2 & 0,75 & 0,3 & Valid \\
X1.4.3 & 0,81 & 0,3 & Valid \\
X2.1.1 & 0,54 & 0,3 & Valid \\
X2.1.2 & 0,78 & 0,3 & Valid \\
X2.1.3 & 0,67 & 0,3 & Valid \\
X2.2.1 & 0,42 & 0,3 & Valid \\
X2.2.2 & 0,58 & 0,3 & Valid \\
X2.2.3 & 0,48 & 0,3 & Valid \\
X2.3.1 & 0,58 & 0,3 & Valid \\
X2.3.2 & 0,75 & 0,3 & Valid \\
X2.3.3 & 0,79 & 0,3 & Valid \\
X2.4.1 & 0,48 & 0,3 & Valid \\
X2.4.2 & 0,81 & 0,3 & Valid \\
X2.4.3 & 0,73 & 0,3 & Valid \\
Y.1.1 & 0,57 & 0,3 & Valid \\
Y.1.2 & 0,48 & 0,3 & Valid \\
Y.1.3 & 0,67 & 0,3 & Valid \\
Y.2.1 & 0,48 & 0,3 & \\
\hline & & & \\
\hline & & 0 alid \\
\hline
\end{tabular}




\begin{tabular}{llll}
\hline Y.2.2 & 0,78 & 0,3 & Valid \\
Y.2.3 & 0,57 & 0,3 & Valid \\
Y.3.1 & 0,66 & 0,3 & Valid \\
Y.3.2 & 0,75 & 0,3 & Valid \\
Y.3.3 & 0,64 & 0,3 & Valid \\
Y.4.1 & 0,78 & 0,3 & Valid \\
Y.4.2 & 0,57 & 0,3 & Valid \\
Y.4.3 & 0,61 & 0,3 & Valid \\
Y.5.1 & 0,51 & 0,3 & Valid \\
Y.5.2 & 0,41 & 0,3 & Valid \\
Y.5.3 & 0,67 & 0,3 & Valid \\
Y.6.1 & 0,78 & 0,3 & Valid \\
Y.6.2 & 0,81 & 0,3 & Valid \\
Y.6.3 & 0,75 & 0,3 & Valid \\
Y.7.1 & 0,67 & 0,3 & Valid \\
Y.7.2 & 0,48 & 0,3 & Valid \\
Y.7.3 & 0,67 & 0,3 & Valid \\
Y.8.1 & 0,84 & 0,3 & Valid \\
Y.8.2 & 0,57 & 0,3 & Valid \\
Y.8.3 & 0,67 & 0,3 & Valid \\
\hline Primary data sources that have been provided by SPSS.
\end{tabular}

\subsection{Reliability Test Result}

Reliability is a measurement that shows the stability and consistency of a variable that measures a concept to access from a measurement Sugiyono (2004: 460). The reliability test is conducted to test whether the answers of the respondents are consistent or stable. A research variable is said to be reliable if it meets the following criteria:

4.3 If Cronbach Alpha $>0.6$ is said to be reliable

4.4 If Cronbach Alpha $<0.6$ is said to be unreliable

Table 2. Reliability Test Result

\begin{tabular}{ccl}
\hline Variable & Cronbach's Alpha & Decision \\
\hline X1 & 0,784 & Reliable \\
X2 & 0,754 & Reliable \\
Y & 0,746 & Reliable \\
\hline \multicolumn{3}{r}{ Source: Data processed by SPSS }
\end{tabular}

Based on the table above, it can be concluded that all statement is reliable. This can be seen from Cronbach's value Alphas that are far greater than the Reliable level $>0.60$. With words others that all statements in this study have a good level of reliability and can be used in the analysis of this study. The results of the reliability values in the table above, mean that the data variables of the application of $\mathrm{K} 3$ (X1) policy, the formation of $\mathrm{P} 2 \mathrm{~K} 3(\mathrm{X} 2)$, and the level of employee safety and health $(\mathrm{Y})$ obtained through questionnaires are said to be reliable. In other words there is consistency of respondents in answering the questionnaire submitted in this study. 


\subsection{Multiple Linear Regression Test Result}

Table 3. Coefficients ${ }^{\mathrm{a}}$

\begin{tabular}{|c|c|c|c|c|c|}
\hline & B & $\begin{array}{c}\text { Std } \\
\text { error }\end{array}$ & Beta & $\mathbf{t}$ & Sig \\
\hline Constant & 7,545 & 2,329 & & 2,329 & .002 \\
\hline K3 Policy & .237 & .087 & .237 & 2,728 & .008 \\
\hline Est of P2K3 & .266 & .131 & .260 & 2.963 & .338 \\
\hline \multicolumn{6}{|c|}{ Table 4. Summary Model ${ }^{b}$} \\
\hline $\mathbf{R}$ & R Squrae & $\begin{array}{l}\text { Ajuusted } \\
\text { RSqurae }\end{array}$ & \multicolumn{2}{|c|}{$\begin{array}{c}\text { Std error } \\
\text { of estimate }\end{array}$} & $\begin{array}{c}\text { Durbin- } \\
\text { witson }\end{array}$ \\
\hline $.669^{\mathrm{a}}$ & .369 & .803 & \multicolumn{2}{|c|}{2.00100} & 2.227 \\
\hline \multicolumn{6}{|c|}{ Table 5. Anova ${ }^{b}$} \\
\hline & $\begin{array}{l}\text { Sum Of } \\
\text { Square }\end{array}$ & Df & $\begin{array}{c}\text { Mean } \\
\text { Square }\end{array}$ & $\mathbf{F}$ & Sig \\
\hline Regresion & 1526,077 & 3 & 508,692 & 127.046 & $.000^{\mathrm{a}}$ \\
\hline Residual & 360,360 & 90 & 4.004 & & \\
\hline Total & 1886.436 & 93 & & & \\
\hline
\end{tabular}

Based on the data output of the tables above, the following results can be obtained:

a) The regression model obtained was $\mathrm{Y}=7,545+0,237 \mathrm{X}_{1}+0,260 \mathrm{X}_{2}$

A constant of 7,545 states that without a K3 (X1) policy and the Establishment of P2K3 (X2), occupational safety and health would still be formed at 7,545. K3 policy variable (X1) has a positive effect on occupational safety and health with a coefficient value of 0.237 . This means that if the K3 policy variable increases by one unit assuming the variable $\mathrm{P} 2 \mathrm{~K} 3\left(\mathrm{X}_{2}\right)$ is fixed, then occupational safety and health will decrease by 0.237 . The variable formation of $\mathrm{P} 2 \mathrm{~K} 3$ (X2) has a positive effect on occupational safety and health with a coefficient value of 0.260 . This means that if the formation variable $\mathrm{P} 2 \mathrm{~K} 3$ (X2) increases by one unit assuming the policy variable K3 (X1) is fixed, then occupational safety and health will decrease by 0.260 .

b) $\mathrm{R}$ square value $\left(\mathrm{R}^{2}\right)$ of 0.369

This means that the data indicate that the K3 policy and the establishment of P2K3 together contributed $36.9 \%$ to occupational safety and health and the remaining $63.1 \%$ was influenced by other variables outside this study.

c) The F-calculated value is greater than the F-table of $127.046>1.987$ with a significance of $\mathrm{F}$ of $0.000<0.05$, then $\mathrm{H} 4$ is accepted and $\mathrm{H} 0$ is rejected. This shows that the OSH policy variable and the formation of $\mathrm{P} 2 \mathrm{~K} 3$ together have a positive and significant effect on occupational safety and health. 


\section{Conclusion}

Based on the results of the analysis and discussion, the following conclusions can be drawn:

a) Based on the descriptive test results the application of $\mathrm{K} 3$ policy has a value of $63.22 \%$ with the most dominant dimension being resources. Whereas the formation of P2K3 has a value of $67.46 \%$ with the most dominant dimension being the clarity of the relationship to be achieved, meaning that in general the application of K3 policy and the formation of P2K3 is strongly supported by the employees of PT Yuasa Battery Indonesia.

b) The implementation of K3 policy affects the level of occupational safety and health of PT Yuasa Battery Indonesia's employees by $23.7 \%$, the rest is explained by other variables and other factors.

c) The formation of P2K3 influences the level of occupational safety and health of PT Yuasa Battery Indonesia's employees by $26.0 \%$, the rest is explained by other variables and other factors.

d) The implementation of K3 policy and the establishment of P2K3 simultaneously influence the level of safety and work health of employees of PT Yuasa Battery Indonesia by $36.9 \%$, the rest is explained by other variables in this study and and the factor that most influences the level of occupational safety and health is the formation P2K3.

\section{References}

[1] Derita Qurbani, Upay Selviana 2018. Pengaruh Keselamatan dan Kesehatan Kerja (K3) Terhadap Kinerja Karyawan ( Studi Kasus Pekerja Proyek Pada PT Trakindo Utama Cabang BSD ), Volume 1. No. 3 (2018). Hal 110 - 129 Jurnal Ilmiah Manajemen Forkamma Pascasarjana Universitas Pamulang

[2] Balai Hiperkes dan Keselamatan Kerja Dinas Tenaga Kerja dan Transmigrasi Provinsi DKI Jakarta. 2009. Himpunan Peraturan Perundangan Kesehatan Kerja. Jakarta.

[3] Buraena, S. 2004. Program Kesehatan Lingkungan Pedoman Kesehatan dan Keselamatan Kerja (K3). RSUP. Dr. Wahidin Sudirohusodo. Makassar.

[4] BPJS Ketenagakerjaan DKI Jakarta Dunia Usaha Diminta Turunkan Kecelakaan Kerja. Suara Karya. Selasa 22 Januari 2013. Jakarta.

[5] Direktorat Pengawasan Norma K3 Direktorat Jenderal Pembinaan Pengawasan Ketenagakerjaan Kementerian Tenaga Kerja dan Transmigrasi. 2012. Himpunan Peraturan PerundangUndangan Keselamatan dan Kesehatan Kerja. Jakarta.

[6] Korandus, Danggur. 2012. Keselamatan dan Kesehatan Kerja. PT Percetakan Penebar Swadaya.Jakarta.

[7] Markkanen, Pia K. 2004. Keselamatan dan Kesehatan Kerja di Indonesia.

[8] Philippines International Labour Organization (ILO)

[9] Rachmatia, Indah.2015.Kesehatan dan keselamatan LingkunganKerja.

[10] Gadjah Mada University Press. Yogyakarta.

[11] Ramli, Soehatman. 2010. Sistem Manajemen K3: Keselamatan dan Kesehatan Kerja OHSAS 18001. Dian Rakyat. Jakarta.

[12] Ridley, John. 2004. Kesehatan Dan Keselamatan Kerja. Erlangga. Jakarta.

[13[ Setyawati, L. M. 2007. Promosi Kesehatan dan Keselamatan Kerja, Pelatihan Para Medis Seluruh Jawa Tengah. RSU Soeradji Klaten.

[14] Suma'mur P. K. 1993. Keselamatan Kerja dan Pencegahan Kecelakaan. Haji 
Massagung.Jakarta.

[15] Tarwaka, PGDip.Sc.,M.Erg. 2014. Keselamatan dan Kesehatan Kerja (K3):Manajemen dan Implementasi K3 di Tempat Kerja. Harapan Press. Surakarta.

[16] Thalib, D. 2004. Higene Perusahaan-Industrial Hygiene in: Kebijakan Keselamatan dan Kesehatan Kerja Pertamina. Jakarta.

[17] Yuasa Battery Indonesia, PT. 2016. Dokumen P2K3. Tangerang. 